\title{
The Use of Different Sewing Methods in Tilapia (Oreochromis niloticus) Fish
}

\author{
Sükrü ÖNALAN* Tunahan SANCAK \\ Van Yuzuncu Yil University, Fisheries Faculty, 65080, Van, Turkey
}

How to cite: Önalan, Ş. \& Sancak, T. (2020). The Use of Different Sewing Methods in Tilapia (Oreochromis niloticus) Fish. J. Anatolian Env. and Anim. Sciences, 5(3), 373-377.

Atıf yapmak için: Önalan, Ş. \& Sancak, T. (2020). Tilapia (Oreochromis niloticus) Balıklarında Farklı Dikiş Yöntemlerinin Kullanımı. Anadolu Çev. ve Hay. Dergisi, 5(3), 373-377.

D. https://orcid.org/0000-0003-0058-5232 (iD): https://orcid.org/0000-0002-7813-1575

*Corresponding author's: Şükrü ÖNALAN

Van Yuzuncu Yil University, Fisheries Faculty, 65080, Van, TÜRKIYE

\: sukruonalan@yyu.edu.tr

Mobile telephone : +90 (530) 9639617

\begin{abstract}
In this study, it is aimed to compare the sewing methods in wounds created for different purposes in the field of aquaculture. For this purpose, Tilapia fish, which took second place after carp in the inland waters fish breeding of hot countries, were used. In the study, Control group $(\mathrm{n}=3)$, simple suture, $\mathrm{U}$ suture and $\mathrm{X}$ (Sultan) suture applications were performed. The fish were subjected to 7 days of adaptation before starting the study. During the study, feeding was done once a day with Tetra Discus food. For the formation of cut wounds, scales were removed in Tilapia fish under anesthesia, and $2 \mathrm{~cm}$ long incision was performed. As a result of the study, it was observed that the cut wounds were closed on the 6th day in the U suture group, at the end of the 7th day in the control group and simple suture groups, and the 9th day in the $\mathrm{X}$ suture group. It was observed that the absorbable suture materials were absorbed in all fish in which they were applied, but in the X suture group, 1 fish was absorbed in the end of the 9th day. It is concluded that it is healthier to prefer simple suture and $\mathrm{U}$ suture primarily in areas such as marking, remote sensing, monitoring and management of fish methods, and fish health.
\end{abstract}

Keywords: Fish diseases, Oreochromis niloticus, sewing methods, wound.

\section{Tilapia (Oreochromis niloticus) Balıklarında Farklı Dikiş Yöntemlerinin Kullanımı}

*Sorumlu Yazar:

Şükrü ÖNALAN

Van Yüzüncü Yıll Üniversitesi, Su Ürünleri

Fakültesi, 65080, Van, TÜRKIYE

凶: sukruonalan@yyu.edu.tr

Cep telefonu : +90 (530) 9639617
Öz: Bu çalışmada, su ürünleri alanında farklı amaçlarla oluşturulan yaralarda dikiş metotlarının karşılaştırılması amaçlanmıştır. Bu amaçla, Sicak ülkelerin iç sular balık yetiştiriciliğinde sazanlardan sonra ikinci sırayı alan Tilapia balıkları kullanılmıştır. Çalışmada, Kontrol grubu $(n=3)$, Basit dikiş, U dikişi ve X (Sultan) dikişi uygulamaları gerçekleştirilmiştir. Balıklar çalışmaya başlamadan önce 7 günlük adaptasyona maruz bırakılmıştır. Çalışma esnasında Tetra Discus yemi ile günde bir kez yemleme gerçekleştirilmiştir. Kesik yarası oluşumu için anestezi altındaki Tilapia balıklarında pullar kaldırılarak $2 \mathrm{~cm}$ uzunluğunda esizyonlar gerçekleştirilmiştir. Çalışma sonucunda kesik yaralarının U dikişi grubunda 6. günde, Kontrol grubu ve basit dikiş gruplarında 7. Günün sonunda ve X dikişi grubunda 9. günde kapandığı gözlenmiştir. Kullanılan emilebilir özellikteki dikiş ipliklerinin uygulandığı tüm balıklarda emildiği ancak X dikişi grubunda 1 balıkta 9. günün sonunda emildiği gözlenmiştir. Dikiş metotlarının balıklarda markalama, uzaktan algılama, izleme ve yönetim, balık sağlığ gibi kullanım alanlarında basit dikiş ve U dikişinin öncelikli olarak tercih edilmesinin daha sağlıklı olduğu kanaatine varılmıştır.

Anahtar kelimeler: Balık hastalıkları, dikiș metotları, Oreochromis niloticus, yara. 


\section{INTRODUCTION}

Tilapias are a group of fish that belong to order Teleostei and family Cichlidae. Tilapias are divided into three main genera; Oreochromis, Tilapia and Sarotherodon. There are four tilapia species in Egypt; Nile tilapia (Oreochromis niloticus) blue tilapia (Oreochromis aureus), white tilapia (Sarotherodon galilaeus) and green tilapia (Tilapia zillii) (El-Sappah et al., 2017). Tilapia (Oreochromis niloticus) is one of the most farmed fish species worldwide, with a global annual production of several million tons (Cui et al., 2019).

Invertabrates, one of the skin's most adequate functions is to provide effective barriers between the organism and the environment. Any damage to the skin causes tissue or cell damage and loss of this barrier (Verma et al., 2017). Skin wounds caused by mechanical trauma or other pathogens form an entry portal for water patterns. At the same time, it causes fish to be exposed to acute imprisonment stress, causing losses in their skin, making them more susceptible to serious water infections. It is important to closely monitor wounds for secondary infections in fish (Noga, 2010).

Fish can injure each other by rubbing on decorative stones in the aquarium until they get used to the aquarium environment (Alderton, 2008) or attacking during the mating period (Bailey \& Sandford, 1998). If these lesions are small, isolation is provided in the affected fish and recovery is achieved without the need for treatment as long as they are closely monitored for secondary wound infections (Noga, 2010). In injuries that may occur in aquariums, due to the potential of bacteria multiplying in an aquarium, more attention should be paid to the risks (Trust \& Money, 1972, Lesconko et al., 2003).

Some instruments have been developed to measure fish clusters in open waters, the degree of sociability of individuals, swimming speeds or cluster radii (Capello et al., 2013). These devices are placed in fish using surgical procedures (Dagorn et al., 2007). After the devices are placed, they are covered with different suture materials, from staples to absorbable suture, according to the size of the fish (Meyer et al., 2000; Dagorn et al., 2007).

Among the injured tissues, new tissues are formed and cicatrization occurs. Cicatrization is a natural process and this process can be accelerated by supporting the healing efforts of injured tissues. For this purpose, it contributes positively to the healing process prevent the presence of a foreign body between the wound lips and allow the wound lips to approach each other (Samsar \& Akın, 2003). For this purpose in sutures, applications are performed to help accelerate the cicatrization in tissues whose tissue integrity is impaired, contribute to the regular return of tissues from the anatomical aspect and restore physiological function (Aslanbey, 2002).
This study aims to try different sewing methods on the experimentally formed incision wounds in fish and determine their usability in different studies in the future.

\section{MATERIAL AND METHOD}

Fish material: The study was carried out with the permission obtained from Van Yüzüncü Yıl University, Animal Experts Local Ethics Committee with the decision dated 31.03.2020 and numbered 25198. The experimental part of the study was carried out with the permission of Van Yüzüncü Y1l University Water Creatures Trial Unit (SUCAN) dated 12.03.2020 and numbered SUCAN003. Tilapia (Oreochromis niloticus) fish (average 100g) used in the study were obtained from a licensed trial unit (SUCAN).

The experimental setup: The fish are placed in aquariums of $50 \times 30 \times 45 \mathrm{~cm}$ with water that is rested in all groups (Fig 1). A filter, air motor and thermometer are installed in the aquarium. The water temperature was kept at $24{ }^{\circ} \mathrm{C}$ throughout the study.The fish were kept in adaptation for seven days (Sarıyyüpoğlu, 2017). Feeding was carried out in the period following the adaptation. On the day of the cut, the fish were starved. Then, feeding was performed once a day throughout the study.

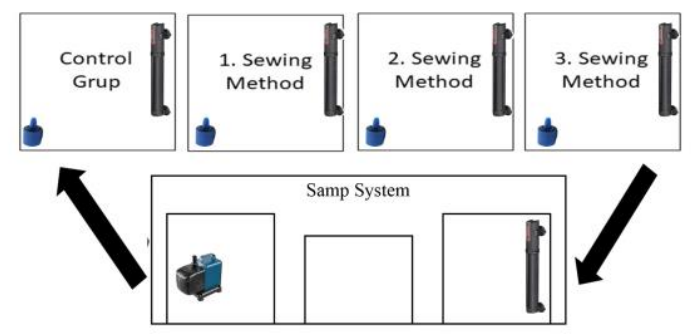

Figure 1. The experimental setup used in the study. Şekil 1. Çalışmada kullanılan deneme düzeneği.

Wound formation: 9 Tilapia (Oreochromis niloticus) fish were used in the study. After general anesthesia with 2-Phenoxyethanol in fish, a $2 \mathrm{~cm}$ long incision wound was formed in the pectoral region under sterile conditions (Sar1eyyüpoğlu, 2017). No anesthetic substance was given for the induction of anesthesia, as the incision wound creation and stitching processes take approximately 40 seconds. After the procedures were finished, when the fish were thrown into the aquariums, they woke up from anesthesia on average within 75 seconds and started swimming again.

Suture techniques: In this study, absorbable synthetic suture material (self-needle braided polyglycolic acid suture) (PGA USP 3/0) was used. Different suture 
methods are used in different regions according to the wound's size to support wound healing. In this study, created for fish for this purpose, their effectiveness was evaluated clinically using three different suture techniques used in the skin. To provide support in ensuring wound integrity, three separate fishes were applied to 3 fish in 3 different groups, simple separate suture technique in group 1, "U" suture technique in group 2 and SULTAN or $\mathrm{X}$ suture technique in group 3 (Aslanbey, 2002). In the cut wound formed as $2 \mathrm{~cm}$, the simple separate suture was applied as two pieces and in other suture applications as one piece.

Differences between suture technique: Simple suture, the most used suture technique, is a suturing used in almost all operations. In this suture, after the inflammation that may occur in the wound, it provides drainage and treatment by taking only one suture without destroying the other sutures. "U" suturing is a suture technique called by different names (Reverse direction suture, four-point suture, separate cushion suture and Halsted suture). In the wounds where this method is applied, a quicker and more precise cicatrization occurs. " $\mathrm{X}$ " or SULTAN suture is a unique suture technique. Such sutures are applied in some cases for a more comfortable and healthier suture. This suture is used to meet excessive pressure and tension (Aslanbey, 2002).

Application of suture techniques: The simple suture technique is firstly immersed in the outside and then in the opposite wound lip from the inside and then, after the wound lips are crossed, the surgical knot is made enough and tightened and the suture is finished. The distance between the seams should be $0.5-1 \mathrm{~cm}$ according to the wound length and tissue thickness. In the "U" suture technique, after starting as in the simple suture, after leaving the opposite wound lip, this time, the needle is inserted in the opposite direction, and the ends of the thread, which take the shape of the letter $U$, are knotted on one side of the wound. In this suture, the wound lips close to each other by forming folds. In the " $\mathrm{X}$ " or sultan suture, the wound is knotted on the inner side of the lips, perpendicular to the wound line, and outside the wound, knotted and sutured (Aslanbey, 2002).

Microbial growth of the wound area: The study was carried out with a closed-circuit UV system. On the firsth and seventh days of the incision wound formation, cultivations were made from the wound area to the TSA medium. There was no bacterial growth in the media after the 24-hour incubation period at 21 and $37{ }^{\circ} \mathrm{C}$ in the TSA medium. This is because the water is believed to result from the filter and UV properties during the recirculation process. Furthermore, accumulation of fluid in the wound or abscess formation was observed (Önalan, 2019).

\section{RESULTS}

\section{Incision formation on the skin of tilapia fish}

In the study, $2 \mathrm{~cm}$ lengths and skin thickness cuts were applied to 3 fish samples in all groups except the control group (Fig 2). Before the cut application, the fish were anesthetized in an aquarium prepared with 2Phenoxyethanol at a rate of $0.4 \mathrm{ml} / \mathrm{L}$. After the incision wound formation that performed under anesthesia, the fish were taken back to the group aquariums after they were expected to get out of anesthesia in aquariums with increased oxygen levels. There was no feeding for 6 hours before and after anesthesia. Apart from these periods, feeding was continued.

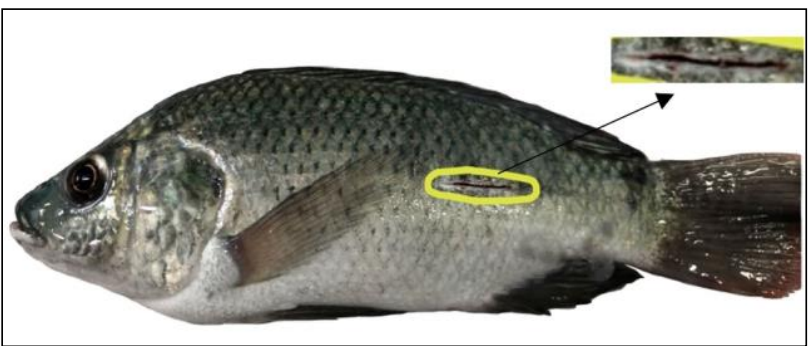

Figure 2. The cut wound created in the study.

Şekil 2. Çalışmada oluşturulan kesik yarası.

Suture applications on the wound: It was determined that entering time in anesthesia 2-3 min, the recovery time from anesthesia 4-6 min. Suture applications of the incision wound in fish that were performed under aseptic conditions (Fig 3). The suture application was completed in approximately 80 seconds for each fish after the incision. After the suture application, a one-time pain relief pomade was performed and the fish was left back to the group aquariums after wake up from anesthesia.

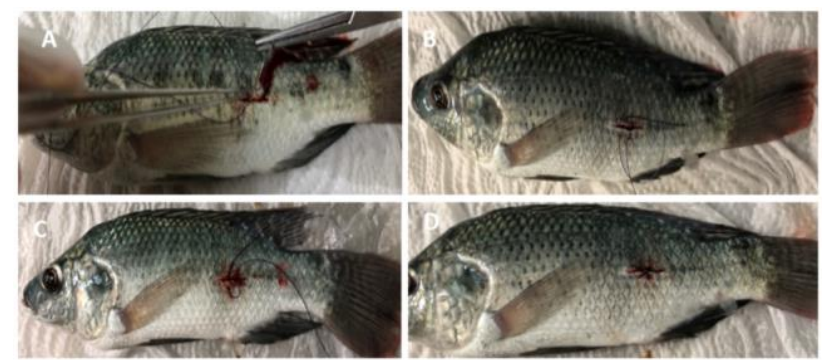

Figure 3. Suture application on the skin (A: Simple suture-1, B: Simple suture -2, C: U suture, D: X suture).

Şekil 3. Deri üzerinde dikiş uygulaması (A: Basit dikiş-1, B: Basit dikiş-2, C: U dikişi, D: X dikişi).

Monitoring wound healing after application: Daily feeding and follow-up were carried out after the suture application. The formation of inflammation around the wound lips and fluid accumulation mainly in the subcutaneous connective tissue were examined. Also, absorption processes of absorbable suture materials were followed. As a result of the study, it was observed that the 
cut wounds were closed at the 6th day in the $\mathrm{U}$ suture technique group, at the end of the 7th day in the control group and simple suture technique groups, and in the 9th day in the $\mathrm{X}$ suture technique group. It was observed that the absorbable sewing threads used were absorbed in all fish, but in the $\mathrm{X}$ suture techniques group, one fish was absorbed in the end of the 9th day.

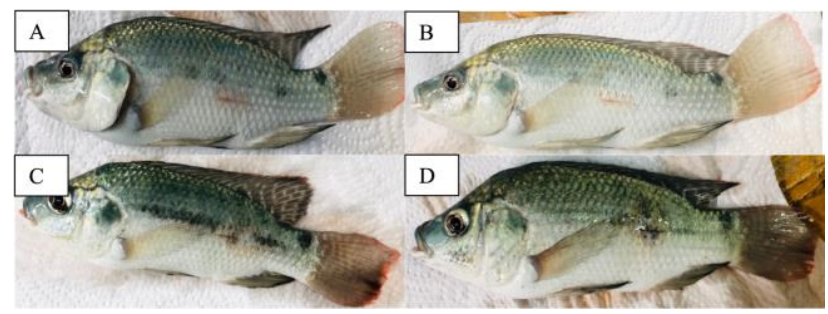

Figure 4. Images of the fish in the different suture group after wound healing (A: Control, B: Simple suture, C: U suture, D: X suture).

Şekil 4. Yara iyileşimi sonrasında farklı dikiş gruplarındaki balıkların resimleri (A: Kontrol, B: Basit dikiş, C: U dikişi, D: X dikişi).

Microbial growth of the wound area: The study was carried out with a closed-circuit UV system. On the first and seventh days of the incision wound formation, cultivations were made from the wound area to the TSA medium. There was no bacterial growth in the media after the 24-hour incubation period at 21 and $37{ }^{\circ} \mathrm{C}$ in TSA medium. This is because the water is believed to result from the filter and UV properties during the recirculation process. Furthermore, accumulation of fluid in the wound or abscess formation was observed.

\section{DISCUSSION AND CONCLUSION}

Nowadays, electronic devices with many different features are used to monitor movement, swimming performance, behavior, growth, physiology and mortality in fish. These devices are implanted into fish by surgical operations (Cooke et al., 2003). Researchers prefer different types of sutures for these operations. These choices are generally related to personal preference and many types of sutures are used successfully in fish (Harms and Lewbart, 2000). The non-absorbable suture materials used for the seam of the skin lose their physical properties in a small amount without losing mass and remain in the body. These should be taken after recovery is achieved when used for the skin instead of absorbent threads (Gemci \& Ulcay, 2004).

The absorbable suture materials are available naturally and synthetically. The body's defense system absorbs naturally absorbable materials, and almost all of them cause partial tissue reaction. On the contrary, synthetic suture materials are destroyed by nonenzymatic hydrolysis and their absorption rates are not significantly affected in the presence of infection or inflammation. These have two characteristics that determine the behavior of living tissues. These are the absorption rate, mass loss and tensile strength protection. Although the absorption rate is important in suture complications, maintaining tensile strength is important as a guarantee of maintaining the tissue approach during healing. The most commonly used absorbable suture materials are catgut, polyglycolic acid, polyglactin, polydioxanone, polymethylene carbonate and polyglycapron 25 (Gemci \& Ulcay, 2004; Karasu \& Bakır, 2006). Also, monofilament synthetic nonabsorbable suture materials (Cooke et al., 2003; Wagner \& Cooke, 2005; Wagner \& Cooke, 2011), stapler (Meyer et al., 2000; Noga, 2010) and absorbable sutures (Dagorn, 2007; Jepsen et al., 2008) have been reported by this researchers that it is used for fish skin sutures.

Tilapia fish seem healthier in terms of skin protein than warm-blooded animals. The reason for this is interpreted that the collagen obtained from the skin in tilapia fish has high tensile strength and correct physical properties for use in wound healing. As a result of the same study, stating that the collagen from Tilapia skin is hydrophilic and thermally stable, it means that the collagen has a high denaturation temperature of $45^{\circ} \mathrm{C}$, that is, it will not lose its form at body temperature for humans and most animals. Therefore, leather has great importance in fish skin, especially in tilapia fish (Zhou et al., 2015). This also means maintaining structural integrity during skin movements.

In fish slits opened for different purposes in fish, sutures are used to close them. Because suture threads support tissue healing during the wound repair process (Karasu \& Bakır, 2006). The simple suture technique, the most used suture technique, is a suturing used in almost all operations. This suture technique provides drainage and healing by taking only one suture after the inflammation that may occur in the wound without damaging the other sutures. "U" suture technique is a suture method that is also called by different names (reverse direction suture, fourpoint suture, separate cushion suture and Halsted suture). In the wounds where this method is applied, a quicker and more precise cicatrization occurs. "X" or SULTAN suture technique is a special suture shape. Such suture techniques are applied in some cases for a smoother and stronger suture (Aslanbey, 2002). In accordance with the effects of suture techniques on the usage areas, according to the data obtained as a result of our study; in wounds formed in fish, it was observed that the suture "U" was absorbed on the 6th, the simple suture on the 7th and the " $\mathrm{X}$ " suture on the 9th day.

In this study, absorbable synthetic suture material (self-needle braided polyglycolic acid suture) (PGA USP $3 / 0)$ was used. These suture materials also provide convenience in ending the study by preventing the fish from being anesthetized and stressed again due to being 
absorbed after a certain period time. In this study, their roles in wound healing compared to each other were clinically observed using three different suture techniques. In the study, it was observed that the wounds that were closed with the suture " $U$ " heal faster (day 5), and the wounds that were closed with the simple suture (day 6) and the wounds that were closed with the " $\mathrm{X}$ " suture (day 7) were closed later.

After suture techniques, no inflammation was observed in the wound area. It has been observed that the absorbable suture material used in the study are at a level that does not affect the wound closure rate in the water. This shows that they have an advantage over nonabsorbable suture materials.

As a result, it has been observed that absorbable suture material can be used safely in fish operations if acted in accordance with the asepsis conditions and it has been understood that " $U$ " sutures provide faster healing in suturing applications cover open wounds in fishes and that healthier studies can be performed using this suture method.

\section{REFERENCES}

Alderton, D. (2008). Encyclopedia of Aquarium \& Pond Fish. Dorling Kindersley, China. p.94.

Aslanbey, E. (2002). Veteriner genel operasyon bilgisi. Medipres, Ankara, 147-172.

Bailey, M. \& Sandford, G. (1998). The new guide to aquarium fish. Anness Publishing, United Kingdom. p.64.

Capello, M., Soria, M., Potin, G., Cotel, P. \& Dagorn, L. (2013). Effect of current and daylight variations on small-pelagic fish aggregations (Selar crumenophthalmus) around a coastal fish aggregating device studied by fine-scale acoustic tracking. Aquatic Living Resource, 26(1), 63-68.

Cooke, S.J., Graeb, B.D.S., Suski, C.D. \& Ostrand, K.G. (2003). Effects of suture material on incision healing, growth and survival of juvenile largemouth bass implanted with miniature radio transmitters: case study of a novice and experienced fish surgeon. Journal of Fish Biology, 62(1), 1366-1380.

Cui, M., Zhang, H., Li, J., Liu, R., Wu, M., Xu, D. \& Zhang, Q. (2019). Differential PCR detection of Streptococcus agalactiae and Streptococcus iniae in tilapia (Oreochromis niloticus) by a single primer pair. Journal of fish diseases, 42(8), 1211.

Dagorn, L., Holland, K.N. \& Itano, D.G. (2007). Behavior of yellowfin (Thunnus albacares) and bigeye ( $T$. obesus) tuna in a network of fish aggregating devices (FADs). Marin Biology, 151(1), 595-606.

El-Sappah, A.H., Shawky, A.S.H., Sayed-Ahmad, M.S. \& Youssef, M.A.H. (2017). Estimation of heat shock protein 70 (hsp 70) gene expression in nile tilapia (Oreochromis niloticus) using quantitative RealTime PCR. Zagazig Journal of Agricultural Research, 44(3), 1003-1015.
Gemci, R. \& Ulcay, Y. (2004). Ameliyat iplikleri tipleri özellikleri ve krome katgüt ile normal katgüt arasindaki mukavemet farklari. Uludağ Üniversitesi Mühendislik Mimarlık Fakültesi Dergisi, 9(2), 95105.

Harms, C.G. \& Lewbart, G.A. (2000). Surgery in fish. Veterinary Clinics of North America: Exotic Animal Practice, 3(3), 759-774.

Jepsen, N., Mikkelsen, J.S. \& Koed, A. (2008). Effects of tag and suture type on survival and growth of brown trout with surgically implanted telemetry tags in the wild. Journal of Fish Biology, 72(1), 594-602.

Karasu, A. \& Bakır, B. (2006). Veteriner cerrahide kullanılan dikiş materyalleri. YYÜ Veteriner Fakültesi Dergisi, 17(1-2), 37-44.

Lescenko, P., Matlova, L., Dvorska, L., Bartos, M., Vavra, O., Navratil, S., Novotny, L. \& Pavlik, I. (2003). Mycobacterial infection in aquarium fish. Veterinary Medicine-Czech, 48(3), 71-78.

Meyer, C.G., Holland, K.N., Wetherbee, B.M. \& Lowe, C.G. (2000). Movement patterns, habitat utilization, home range size and site fidelity of whitesaddle goatfish, Parupeneus porphyreus, in a marine reserve. Environmental Biology of Fishes, 59(1), $235-242$

Noga, E.J. (2010). Fish disease diagnosis and treatment. Second Edt. Wiley-Blackwell, USA. 13-48p.

Önalan, Ş. (2019). Expression differences of stress and immunity genes in rainbow trout (Oncorhynchus mykiss, Walbaum 1792) with different bacterial fish diseases. The Israeli Journal of AquacultureBamidgeh. 71(1), 1597-1607.

Samsar, E. \& Akın, F. (2003). Genel cerrahi. Medipress, Malatya, 207-267.

Sarıeyyüpoğlu, M., Özcan, M. \& Barata, S. (2017). Gökkuşağı alabalığı (Oncorhynchus mykiss)'nda deri ensizyonuyla operasyon uygulanması ve balığın canlılığının kontrolü üzerine bir araştırma. Firat Üniversitesi Fen Bilimleri Dergisi, 29(1), 9-13.

Trust, T.J. \& Money, V.G. (1972). Bacterial population of diets for aquarium fishes. Journal of the Fisheries Research Board of Canada, 29(1), 429-433.

Verma, N., Kumari, U., Mittal, S. \& Mittal, K. (2017). Effect of asiaticoside on the healing of skin wounds in the carp Cirrhinus mrigala: An immunohistochemical investigation. Tissue Cell, 49(6), 734-745.

Wagner, G.N. \& Cooke, S.J. (2005). Methodological approaches and opinions of researchers involved in the surgical implantation of telemetry transmitters in fish. Journal of Aquatic Animal Health, 17(1), 160169.

Wagner, G.N. \& Cooke, S.J. (2011). Surgical implantation techniques for electronic tags in fish. Reviews in Fish Biology and Fisheries, 21(1), 71-81.

Zhou, T., Wang, N., Xue, Y., Ding, T., Liu, X., Mo, X. \& Sun, J. (2015). Development of biomimetic tilapia collagen nanofibers for skin regeneration through inducing keratinocytes differentiation and collagen synthesis of dermal fibroblasts. ACS Applied Materials \& Interfaces, 7(5), 3253-3262. 